\title{
Business, Economic Nationalism and Finnish Foreign Trade during the 19th and 20th centuries
}

\section{Jensen-Eriksen, Niklas}

2015

Jensen-Eriksen , N 2015 , ' Business, Economic Nationalism and Finnish Foreign Trade pÿduring the 19th and 20th centuries ' , Revue Française d Histoire Économique - The French pÿEconomic History Review , vol. 1, no. 3 , pp. 4057 .

http://hdl.handle.net/10138/222921

acceptedVersion

Downloaded from Helda, University of Helsinki institutional repository.

This is an electronic reprint of the original article.

This reprint may differ from the original in pagination and typographic detail.

Please cite the original version. 


\title{
Business, Economic Nationalism and Finnish Foreign Trade during the $19^{\text {th }}$ and $20^{\text {th }}$ centuries
}

Niklas Jensen-Eriksen

\begin{abstract}
In this article we look at a country, Finland, where economic nationalism had a major influence on government policy and on the development of business enterprises from the mid-19th century to the end of the millennium. During this time period, the Finns managed to combine export-oriented economic strategy with exceptionally nationalistic economic policies, even though they could not mould international trade regimes in a way that was beneficial for them. Yet, nationalism also had negative effects. Instead of limiting their activities on the protection of truly vital national interests, the Finnish authorities went on to create a highly restrictive system that placed severe obstacles in front of all foreigners who were willing to invest or work in Finland.
\end{abstract}

Social scientists tend to argue that there are three major ideologies or schools of thought in political economy: Marxism, economic liberalism and economic nationalism. ${ }^{1}$ They have also concluded that the last of these has received considerably less attention from scholars than its main competitors. $^{2}$ In recent years, a number of students of International Political Economy have worked hard to fill this gap. While doing so, they have recognised that previous scholarship has not properly analysed the various ways nationalism can influence economic policies and development. In particular, they have underlined the need to look at the specific content of nationalist projects instead of simply labelling protectionist or autarkic policies as economic nationalism. ${ }^{3}$

In this article, we will examine Finland, where economic nationalism has had a major influence on government policy and on the actions and development of business enterprises during the last 150

\footnotetext{
${ }^{1}$ For example, Gilpin, Political Economy, chapter 2; Nakano, "Theorising economic nationalism", 211; Levi-Faur, "Economic nationalism", 359; Helleiner, "Economic Nationalism as a Challenge", 307.

${ }^{2}$ For example, Nakano, "Theorising economic nationalism", 211; Kettunen, The Tension, 286; Levi-Faur, "Economic nationalism", 359.

${ }^{3}$ See for example, Abdelal, National Purpose; Helleiner and Pickel, eds., Economic Nationalism in a Globalizing; Crane, "Economic nationalism."
} 
years. For example, the Finnish legislation on foreign direct investment was, between 1939 and the early 1990s, "arguably the most restrictive in the developed world', as Ha-Joon Chang from the University of Cambridge has written. ${ }^{4}$ The Finnish case is interesting also for two other reasons. Firstly, Finland, originally a poor country compared to most Western European countries or even neighbouring Sweden, managed to catch up with the West. By the end of the millennium, it had become one of the world's wealthiest countries. ${ }^{5}$ Secondly, the Finns combined export-oriented economic strategy with exceptionally nationalist economic policies, even though they, as representatives of a small country, could not modify international trade regimes to suit them.

This article discusses the origins and role of economic nationalism in Finland. We are able to build partly on the earlier work done by several Finnish scholars, in particular Markku Kuisma, Riitta Hjerppe, Karl-Erik Michelsen and Timo Myllyntaus ${ }^{6}$, but are also able to take advantage of the insights of recent theoretical literature on economic nationalism, which has not been properly applied to this case.

It is suggested that the strong Finnish growth performance was to a large degree a result of the creation of a successful export-oriented national strategy, but that economic nationalism had also negative side effects which undermined Finnish economic development and its ability to adapt to economic globalisation. These negative effects have often been overlooked in historical research.

\section{New theoretical perspectives on economic nationalism}

The relative lack of interest on economic nationalism is partly due to the fact that it, unlike socialism or liberalism, is not a coherent theoretical construction. ${ }^{7}$ Friedrich List, the most important advocate of economic nationalism during the $19^{\text {th }}$ century, underscored the need to protect infant industries with protectionist tools. Since then, economic nationalism has commonly been associated with protectionist or autarkic policies, as well as policies that support domestic industries or place restrictions on foreign direct investment. Ironically, the concept has been much more popular among liberals than amongst the (alleged) nationalists. Liberals tend to classify as

\footnotetext{
${ }^{4}$ Chang, "Regulation", 697.

${ }^{5}$ In more detail, see Ojala, Eloranta, and Jalava, eds., The Road to Prosperity. The book also includes extensive quantitative evidence.

${ }^{6}$ Kuisma, "Government Action"; __ Cooperation; Michelsen and Kuisma, "Nationalism", Myllyntaus, "The Finnish Model"; Hjerppe and Ahvenainen, Foreign enterprises; Hjerppe, "Significance."

${ }^{7}$ Gilpin, Political Economy, 31.
} 
economic nationalism a wide variety of policies that they dislike and find incompatible with liberal ideals of free trade and non-intervention of governments in economic affairs. ${ }^{8}$ During the era of globalization, many observers have regarded economic nationalism as a relic from earlier unhappy days or an irrational backlash that can only hinder world trade and development. ${ }^{9}$

In interwar era, economic nationalism received considerable attention from various scholars, but during the Cold War, bilateral perspective focusing on the differences between socialism and liberalism tended to dominate discussions about international economy. From the 1970s onwards, the students of International Political Economy began to give more consideration to the role of economic nationalism. They commonly represented economic nationalism as a statist tradition that emphasised the subordination of private interests to state's needs. It was, therefore, closely linked with the Realist school of International Relations, which underlines the primacy of states in world politics. ${ }^{10}$

A number of scholars, have, however, recently challenged these views. ${ }^{11}$ They argue, firstly, that political economists have failed to recognize that state and nation are two different things, even though they often overlap. A nation is, according to Benedict Anderson's famous definition, an 'imagined community', i.e., a socially constructed community of people who do not necessarily know each other but who nevertheless believe they are a part of the same group. ${ }^{12}$ Scholars should, therefore, study how nationalist ideas and identities influence economic and other policies. In other words, they should 'bring the nation back in' to the international political economy. ${ }^{13}$

Secondly, the scholars have stressed the goals rather than the methods and tools of economic nationalism. Rereading of Friedrich List's works by Erich Helleiner has offered support for this view. List believed, as Helleiner has emphasised, that the main difference between his thinking and that of the economic liberals was that the latter were interested in promoting the interests of the individual and the humanity on the whole and, therefore, ignored the significance of nations, while for List the latter were crucial entities. List was aiming to develop a 'science which limits its

\footnotetext{
${ }^{8}$ Helleiner, "Economic Nationalism as a Challenge", 308-309.

${ }^{9}$ See, for example, various statements collected by Andreas Pickel. Pickel, "Explaining", 106-110.

${ }^{10}$ Gilpin, Political Economy, is the best known example of this school of thought.

${ }^{11}$ See for example, Abdelal, National Purpose; Helleiner and Pickel, eds., Economic Nationalism in a Globalizing; Crane, "Economic nationalism."

12 Anderson, Imagined communities.

${ }^{13}$ Crane, "Economic nationalism."
} 
teaching to the inquiry of how a given nation can obtain (under existing conditions of the world) prosperity, civilisation and power." 14

In other words, liberals and economic nationalists cannot be separated from each other simply by looking at whether they support free trade or not, but rather by trying to find out why they advocate certain policies. Given that the main goal of nationalists is to promote "prosperity, civilisation and power' of a 'given nation', they can in certain cases support the dismantling of trade barriers instead of protectionism. Hence, free trade policies and high tariffs can both be symptoms of economic nationalism, if the goal is to promote the wealth or power of the nation. ${ }^{15}$ Quebec nationalists have, for example, supported free trade policies because in this way they have become less dependent of the English-speaking majority of Canada. ${ }^{16}$ Andreas Pickel has, therefore, argued that economic nationalism is not opposite of economic liberalism but 'is better understood as a generic phenomenon that can accommodate almost any doctrinal content, including economic liberalism. ${ }^{17}$ David Levi-Faur has identified three elements in distinctively national economic thinking: citizens share or should share 'a common fate'; the state has a key positive role in the economy and guides it forward; and finally that nationalism should guide a state's policies in economic sector. ${ }^{18}$

Based on these kinds of differences and on List's original ideas, Erich Helleiner has asked: 'in what ways do national identities and nationalism influence economic policy and processes'? ${ }^{19}$ In this article we try to answer this question in the Finnish context.

\section{The roots of Finnish nationalism}

From the Middle Ages up to 1809, the area that later became the independent Republic of Finland was a part of the Swedish Kingdom. In the Swedish-Russian war of 1808-1809, the Russian Empire conquered Finland and made it an autonomous Grand Duchy. The Emperor (or Czar) of Russia adopted the title of Grand Duke of Finland, but day-to-day affairs were in the hands of the Finnish Senate, the most important of the new administrative organs set up after the war. Although most of the inhabitants of the country spoke Finnish, the Grand Duchy was led by the Swedish-speaking

\footnotetext{
${ }^{14}$ Helleiner, "Economic Nationalism as a Challenge", 312.

${ }^{15}$ Nakano, "Theorising economic nationalism", 212: Shulman, "Nationalist Sources", 365.

16 , "Nationalist Sources", 375-380.

${ }^{17}$ Pickel, "Explaining", 122.

${ }^{18}$ Levi-Faur, "Economic nationalism", 360.

${ }^{19}$ Helleiner, "Economic Nationalism as a Challenge", 326.
} 
elite, who occupied key positions in all fields of life. Many members of the elite were not, however, Swedes in an ethnic sense, but originated from Finnish-speaking families that had adopted the Swedish language because otherwise they could not have climbed the social ladder.

During the early part of $19^{\text {th }}$ century, nationalism as an ideology spread from other parts of Europe to Finland. Takeshi Nakano has suggested that a 'nation is what the people believe is a nation', ${ }^{20}$ and this subjective definition fits well with the Finnish case. Many early Finnish nationalists originated from the traditional Swedish-speaking elite of the country but nevertheless chose to learn Finnish and became strong advocates of Finnish nationalism. Most Swedish-speakers, roughly 15 per cent of the population at the end of the $19^{\text {th }}$ century, kept their mother tongue yet nevertheless considered themselves Finns, not Swedes who just happened to live in another country. Many Finnish-speakers were not, however, equally convinced of the Finnish status of Swedish-speakers and resented their dominant role in the society. The new Fennoman movement wanted to make Finnish, before mainly the language of peasants and other lower social classes, the leading language of country and build a sophisticated culture based on Finnish traditions.

J.V. Snellman, the most influential figure in the Finnish national movement, managed, inter alia, in 1863 to persuade the Emperor/Grand Duke to raise Finnish to status of an official language of the country, and henceforward Finland has had two official languages, Finnish and Swedish. By the end of $19^{\text {th }}$ century, the Fennoman movement spread its influence from political and cultural fields to economy. The industrialisation of Finland had started gradually during the mid-19 $9^{\text {th }}$ century, but most of the new manufacturing and financial companies were in the hands of the old Swedishspeaking elite. This was hardly surprising because its members had the education, financial resources and connections needed to build new companies. At the end of the century, the Fennomans began to set up companies of their own. These included the insurance company Pohjola and the commercial bank Kansallis-Osake-Pankki (KOP), both of which eventually became leading enterprises in their respective business sectors, as well as manufacturing companies like Kajaani Oy, a forest industry enterprise. ${ }^{21}$

\footnotetext{
${ }^{20}$ Nakano, "Theorising economic nationalism", 217.

${ }^{21}$ See for example, Lyytinen, Pohjola-yhtiöt; Blomstedt, KOP; Keskisarja, Afäärifennomaanit.
} 


\section{Building international industries in Finland}

The Finnish historiography has traditionally underlined that foreign capital played only a relatively small role in the country's industrialisation. ${ }^{22}$ This might strictly speaking be true because multilateral companies played a minute part in the industrialisation of Finland as investors, and some of the individual foreign entrepreneurs that set up companies in the country acquired funding from Finnish sources. Yet, a recent quantitative analysis by a group of historians has shown that the role of foreign entrepreneurs should not be underestimated. They compiled a list of the 30 largest industrial companies (by employment) in Finland in various years of the $19^{\text {th }}$ century and classified them on the basis of nationality. This revealed, for example, that 17 of the companies that made to the list of 1860/1862 were set up by foreigners, while the list of 1890/1891 included 12 such enterprises. $^{23}$

Some of the foreign-owned enterprises were transferred to Finnish hands after bankruptcies or other difficulties. In many other cases, the businessmen gradually assimilated to the domestic business elite. This was by no means a new phenomenon because from the Middle Ages onwards, Finnish cities had attracted foreign merchants, who had moved to the country and then gradually became a part of the local society.

Economic nationalists often see strong foreign involvement in the economy as a threat to their country's independence. Kauppalehti, a business newspaper, argued in 1911 that foreign capital and experts bring economic benefits, but also "break up the national culture." The "foreign habits and languages" damage "a nascent nation just creating a modern, distinguishing culture using its own vernacular." ${ }^{24}$ The Finnish and Russian authorities placed first restrictions on foreign business activities in Finland from 1830s onwards. For example, in 1851 it was decreed that foreigners (except Russian noblemen) had to get a permit from the Czar to buy land. This meant that the country's forests could not move permanently to foreign hands. After 1883 foreigners could not engage in mining operations without a license, and three years later they were forbidden to enter banking business. In 1889, they lost the right to build or operate railroads, and finally in 1895 it was

\footnotetext{
${ }^{22}$ For example, Myllyntaus, "The Finnish Model", 630; Hjerppe and Ahvenainen, Foreign enterprises, 286; YläAnttila, Ali-Yrkkö, and Nyberg, Foreign ownership, 253.

${ }^{23}$ Särkkä, Valtonen, Turunen, and Valtonen, "The economic and social networks of business leaders."

${ }^{24}$ Quoted and translated in Myllyntaus, Electrifying Finland, 61.
} 
decreed that the majority of the board members of a limited liability company had to be Finnish citizens. $^{25}$

As a remote country that had relatively few natural resources and a small domestic market, Finland could not hope to attract as much foreign direct investment (FDI) as many other Western countries. The new restrictions probably discouraged foreign investments even more, though not as much as one could expect. For example, the Norwegians, who had substantial experience in sawmilling, recognised that Finland with its considerable forest resources offered them attractive business opportunities. One did not have to own the land were the trees stood because wood could be bought from landowners or from businessmen who had acquired rights to utilise forests owned by the government or private owners. Many Norwegians moved to Finland from the late 1860s onwards. The best known of these was Hans Gutzeit, whose company W. Gutzeit \& Co. is the predecessor of today's giant Stora Enso. He soon lost of the control of the company to other, mainly Norwegian investors, but according to Jorma Ahvenainen, an academic who wrote the history of the company, it was 'in spirit' Finnish and operated in the same way as other Finnish companies. He, therefore, feels it would have been hard to argue that foreigners were exploiting Finland in any way. ${ }^{26}$

Foreign entrepreneurs brought with them new technology and knowhow, which Finland as a late industrializing country desperately needed. Foreign technicians and other professionals played a central role also in Finnish-owned enterprises. For example, in the Finnish pulp and paper industries, it was customary, up to the beginning of the First World War, to hire German, British, Swedish or Norwegian experts and technical managers to supervise production. Many of these foreigners left the country when the war broke out, but during the interwar period, some leading Finnish-owned companies again hired experts from abroad to key positions. ${ }^{27}$

\section{Building a national economy}

In short, the emerging Finnish industry was during the era of 'first globalisation' very international in outlook. A substantial proportion of owners and management, as well as technical expertise were in the hands of foreigners. Yet, it was not self-evident that foreigners posed a threat to the Finnish

\footnotetext{
${ }^{25}$ Hjerppe and Ahvenainen, Foreign enterprises, 287.

${ }^{26}$ Ahvenainen, Enso-Gutzeit Oy, osa I, 136-137.

${ }^{27}$ Jensen-Eriksen, Kansallinen.
} 
nation or independence, as Kauppalehti feared. Many newcomers were gradually assimilated into the general population, and truly multinational companies had not set their foot in Finland.

More threatening plans had, however, appeared in the horizon. From the 1890s onwards, foreign investors were planning to exploit the Imatra Rapids, which were located in Eastern Finland, to generate energy for St. Petersburg, the Russian capital. The rapids were among best-known tourist attractions of Finland, but they were also the most important potential source of hydropower for the country, which had few alternative sources of energy. If the electricity was directed to St.

Petersburg, the Finnish industry could not utilise this crucial source of power, except perhaps on a limited scale. ${ }^{28}$ A German company, Metallgesellschaft, was also planning to start copper mining operations in Outokumpu, and export the ore to Germany for refining. ${ }^{29}$

Real and imagined attempts by foreigners to exploit Finland's natural resources provided fuel for rising economic nationalism. In 1917, when Finland declared itself independent after the collapse of the Russian Empire, nationalist notions rose forcefully to the surface. The same happened in many other new independent states, which emerged from the ruins of Austro-Hungarian, Russian and German empires in the Eastern half of Europe. For relatively poor countries, which had just freed themselves from foreign domination, economic nationalism offered a way to assert their independence and to promote economic development. ${ }^{30}$

The public opinion and politicians were eager to limit foreign activities in Finnish business life, and new regulations instituted in 1919 reflected this fact. From now on, foreigners had to get a permit to set up a business in Finland, and to guarantee in advance that the government and the municipalities would get required taxes and other charges. ${ }^{31}$ A new law specifically forbid the export of electricity that had been generated from indigenous sources, and hence the hydropower resources of Imatra were reserved for domestic use. ${ }^{32}$

It proved easy to push foreign investors out because many of them were eager to go. A bitter Finnish Civil War in 1918 and political conflicts suggested that the country was politically unstable and that possible re-emergence of the Russian Empire might lead to the loss of Finnish

\footnotetext{
${ }^{28}$ Myllyntaus, Electrifying Finland, 61-71.

${ }^{29}$ Michelsen and Kuisma, "Nationalism", 349.

${ }^{30}$ Kuisma, Cooperation, 412.

${ }^{31}$ Hjerppe and Ahvenainen, Foreign enterprises, 289-290.

${ }^{32}$ Myllyntaus, Electrifying Finland, 71.
} 
independence. Before the collapse of Imperial Germany in November 1918, the Germans also had considerable influence in Finland. The fall of the Russian Empire had left a power vacuum, which the Germans managed to fill for the short period. Allied victory on the Western front and German revolution led to the withdrawal of German troops from Finland and other parts of the former Russian Empire.

Some of the key foreign assets in Finland, like the Norwegian-owned forest industry companies, were soon up for sale. The Finnish government bought W. Gutzeit \& Co. and Tornator Oy, while some other enterprises ended up in the hands of private Finnish investors. ${ }^{33}$ The government also bought the rights for the Outokumpu mine, and eventually set up a new company Outokumpu Oy, which became an important mining company and later a steel producer. ${ }^{34}$ Energy company Imatran Voima was set up to utilise hydropower resources of the Imatra rapids. In the 1930s, the new power plant and other establishments in the same Vuoksi River produced more hydropower than all the other similar plants in the country together. ${ }^{35}$

The government had acquired Gutzeit in order to ensure that the company would not end up in the hands of new foreign owners. The Imperial German government had behind the scenes urged the Finnish government to act so that the company would not end up in the hands of British investors. The Finnish government did as they were urged, but in reality there were even more concerned about the possibility that the company might otherwise acquire German owners. ${ }^{36}$

Yet, the government officials who had organised the purchase of Gutzeit did not only try to enhance the independence of the country, but also shift the balance of power within industry from old Swedish-speaking elite to the rising class of Finnish-speaking managers. This became clear soon after W. Gutzeit \& Co. had moved to the Finnish government's hands. A consortium of Finnish investors offered to buy it from the government. They also agreed to keep the enterprise in their possession and not to resell it to foreign investors. The offer was rejected, ${ }^{37}$ and instead the management of Gutzeit was given to V.A. Kotilainen, Finnish-speaking managing director of Kajaani Oy. Gutzeit and other state-owned companies were now filled with Finnish-speaking

\footnotetext{
${ }^{33}$ Kuisma, Sodasta syntynyt, 136-137.

${ }^{34}$ See - A History of Outokumpu.

${ }^{35}$ Myllyntaus, Electrifying Finland, 86.

${ }^{36}$ Kuisma, Sodasta syntynyt, 149-154

${ }^{37}$ Ibid., 157.
} 
professionals; hence, they became important avenues through which the Finnish middle class could undermine the relative position of Swedish-speakers in the economy. A new breed of executives, which Michelsen and Kuisma have branded as 'patriotic managers', was born. ${ }^{38}$ Many Swedishspeaking executives, in turn, moved to companies controlled by traditional elites.

The Finnish-speaking managers of state-owned companies worked hard to build vast industrial enterprises, which reflected both their personal ambitions and a more general desire to promote the diversification and development of the Finnish economy. After the Second World War, the next generation of 'patriotic managers' led new state-owned companies like Neste Oy, an oil refiner. ${ }^{39}$

\section{Who are we?}

Finnish private companies watched with certain anxiety the expansion of the role of the government in business. Yet, the forest industry, the most important branch of the manufacturing sector, had a bigger potential threat to think about: many influential Finns were not at all convinced that the country should place its fate on industry.

Industrialisation is often considered to be one of the most important aims of economic nationalists. Yet, this is not always the case. Alexander Hamilton and Friedrich List did not reject the importance of agriculture, but rather aimed at balanced development of a society, where both industrial and agricultural groups could survive and prosper. Uneven development of a society could weaken the cohesion of a nation, which from the point of view of nationalists, would have been highly unsatisfactory. ${ }^{40}$

According to Rawi Abdelal, 'What societies want depends on who they think they are'. ${ }^{41}$ In the early decades of the Finnish industrialisation, many nationalist believed that populous independent Finnish-speaking peasantry represented the most 'genuine' and 'natural' part of the country's society. Hence, it should be supported and expanded. Industry, in contrast, was seen as a foreign ingredient that was mainly run by Swedish-speaking 'alien' elements and foreign entrepreneurs, and which undermined traditional social structures of an agrarian society. The Civil War of 1918 seemed to prove that these critics had a point. Urban industrial proletariat had formed the backbone

\footnotetext{
${ }^{38}$ Michelsen and Kuisma, "Nationalism", 351-352.

${ }^{39}$ Ibid., 352.

${ }^{40}$ Nakano, "Theorising economic nationalism", 226.

${ }^{41}$ Abdelal, National Purpose, 1.
} 
of the rebellious 'Red' forces that had tried to take over the country. The victorious 'White' army, i.e., the government's troops, had mainly consisted of Finnish-speaking independent peasants and, to lesser degree, members of the middle classes who were now seen as the saviours of the country. ${ }^{42}$ Furthermore, a severe shortage of foodstuffs during the First World War and the cessation of traditional imports from Russia encouraged the Finns to expand domestic agricultural production. ${ }^{43}$

The timber, pulp and paper companies wanted to expand their land holdings in order to secure their raw materials supply. The farmers and their political supporters opposed this and wanted to keep the land in the hands of agricultural producers. Moreover, many poor families in the countryside were dreaming of a farm of their own. The industrialists lost this political struggle, and laws that severely limited their right to buy land were passed. Hence, most of the Finnish territory remained in the hands of independent peasants, and the industry had to buy wood from them. ${ }^{44}$

The peasantry and their political representatives gradually learned to appreciate the considerable stumpage income the farmers got from industry that had to buy their wood and processed into products sold to foreign countries. Hence, the agrarian interests eventually accepted the vision highlighted by List and Hamilton, namely a balanced society where both industry and agriculture could prosper. The strong role of forest industries gradually became a strong part of Finnish national identity. In short, the relationship between economic processes and nationalism turned out to be a two-way street: nationalism influenced Finnish economic development, but the latter eventually also changed the way the majority of Finns viewed their country: successful and modern industry became a 'natural' part of Finland. ${ }^{45}$

In general, it would be wrong to classify Finnish forest industrialists, regardless of their mother tongue or ethnicity, as anti-Finnish or anti-nationalistic persons. In comparison to most other Finns, export-oriented industrialists were certainly more cosmopolitan in outlook because they had extensive international trading links, better language skills, and greater knowledge of foreign cultures, but their behaviour nevertheless revealed an implicit but clear national perspective toward world trade. The forest industrialists saw themselves as representatives of Finnish industry, not simply independent businessmen. This social cohesion reflected largely economic realities, and in

\footnotetext{
${ }^{42}$ Kuisma, Sodasta syntynyt, 172-177.

${ }^{43}$ Hjerppe and Lamberg, Changing structure, 395.

${ }^{44}$ Kuisma, Cooperation. , 419-422

${ }^{45}$ Compare with Fougner, "Economic Nationalism”, 177.
} 
particular a lack of resources that had forced entrepreneurs throughout the centuries to co-operate with each other when launching large ventures. ${ }^{46}$

In 1917-1918, the loss of the exceptionally vital Russian markets as a result of the disintegration of the Empire forced paper and pulp producers to join forces and to set up joint export associations in order to establish a presence in the non-Russian markets. At the same time, they tried to defend themselves against Imperial Germany, which tried to expand its economic influence in Finland. Although the German threat soon disappeared, the co-operation continued, and for most of the $20^{\text {th }}$ century, the main Finnish export industries operated in the world markets as strong national export cartels and did so in a successful fashion. The poor peripheral small nation eventually became one of the leading producers of pulp, board and paper in the world markets. ${ }^{47}$

In a way, the strict restrictions on FDI gave too negative of an impression on the attitude of the Finns towards international economic exchange. They were eager to keep raw material sources and production capacity in domestic hands, but at the same tried to build an increasingly export-oriented economy. Both the government and private investors, such as commercial banks, which had a strong role in the economy, channelled funds to large forest, engineering and shipbuilding companies that relied on foreign demand. ${ }^{48}$ Although these companies were large entities in Finnish context, they were small in international comparisons, and hence it seemed wise to join forces and set up various co-operative export ventures. Export cartels are not necessarily nationalist organs, but the Finnish industrialists did have a clear national perspective.

\section{Second World War and the Cold War}

New restrictions did not entirely stop the flow of foreign investments to Finland. Predecessors of the Anglo-Dutch food giant Unilever managed to capture a strong role of the Finnish margarine industry in the end of the $1920 \mathrm{~s},{ }^{49}$ and in the beginning of the next decade, a British family company Dixon built a pulp mill in Northern Finland. The Americans, in turn, founded the Insulite Company of Finland Oy, which brought in new technology (to manufacture insulite board) and hence was approved by the authorities. The Finnish government also invited British, German and

\footnotetext{
${ }^{46}$ Ojala and Karonen, Business, 104, 107-108.

${ }^{47}$ See more in Jensen-Eriksen, "A Potentially Crucial Advantage."

${ }^{48}$ See for example, - Läpimurto, chapter 6.

${ }^{49}$ See Avellan, "Margariiniteollisuus."
} 
Belgian chemical giants to set up a joint subsidiary, Finnish Chemicals, in Finland. The plant produced bleaching chemicals for Finnish forest industries, but the government was more interested in the fact that it produced substances important for national defence. ${ }^{50}$

The Dixon family, which needed pulp for their British paper mills, had a close ally in Finland, Gösta Serlachius, one of the country's most influential industrialists. He also agreed to sell a plot of land to Waldhof, a German company which built a pulp mill in Eastern Finland, where he himself did not operate. In internal meetings of the Finnish forest industry, Serlachius spoke in favour of free competition, but most other forest industrialists resented the arrival of the Germans, who were dominant actors in the Northern European paper trade and hence dangerous competitors. Nevertheless, the government, and sellers of wood accepted the entry of Waldhof and Dixon because their greenfield investments created jobs and increased demand for wood in the middle of the Great Depression. Furthermore, as almost all the other plants in the country were in domestic ownership, few individual foreign subsidiaries did not necessarily pose a threat to national security. The authorities did not therefore employ all the legal measures in their disposal to regulate the activities of Waldhof. ${ }^{51}$

Increasing international tension changed all this. By the end of the 1930s, it had become clear that a new world war might erupt, and in 1939, just before it did, the Finnish Parliament accepted proposal that significantly tightened restrictions on foreign ownership of Finnish real estate and the participation of foreigners in Finnish business life. According to these 'draconian' regulations, as Ha-Joon Chang has called them, ${ }^{52}$ foreigners could neither buy land in Finland without government approval nor become board members of managing directors of Finnish-owned companies. The authorities were concerned that non-nationals might nevertheless acquire land indirectly through companies registered in Finland. Therefore, companies' articles of association had to include a rule that foreigners could not buy over 20 per cent of their shares. Companies whose statues did not have this regulation were classified as 'dangerous companies' and hence needed government approval for their real estate acquisitions. ${ }^{53}$ There were also dozens of other laws and regulations that limited foreigners' rights in various fields. They could not, for example, freely lead travel agencies and

\footnotetext{
${ }^{50}$ Michelsen, Sähköstä.

${ }^{51}$ Häggman, Metsän tasavalta, 86-91; Silvennoinen, Paperisydän, 328-331, 338, 345-352.

52 Chang, "Regulation", 697.

${ }^{53}$ Hjerppe and Ahvenainen, Foreign enterprises, 290; "Laki ulkomaalaisten sekä eräiden yhteisöjen oikeudesta omistaa ja hallita kiinteätä omaisuutta ja osakkeita.” H. Berghell. Suomen Paperi-ja Puutavaralehti 19/1939.
} 
auction houses, publish newspapers or work as a real estate agent. ${ }^{54}$ In some cases, it is exceptionally hard to see why the restrictions were necessary.

Events during the late 1940s onwards seemed to suggest that the law of 1939 had been necessary. Finland had managed to avoid Soviet occupation during the Second World War, and retain its democratic political system and capitalist economic structure, but after the war the Soviets tried to use various economic and political means to expand their influence. In the conference of Potsdam in the summer of 1945, the three victorious powers of the Second World War, the United States, the United Kingdom and the Soviet Union, agreed that the Soviets should take over German property in a number of Eastern and Central European countries, including Finland.

The Soviets got less than they probably expected: the strict regulations and the remoteness of Finland had ensured that there were not many German-owned companies in the country. Most of the 65 joint stock companies that the Soviets did acquire were small or otherwise insignificant. Many turned out to be economically weak and could not survive without their previous owners and managers. Politically, they were not, however, totally useless. The Soviets, for example, channelled funds to local communists through these companies. In the mid-1950s, the Soviets decided to give up most of the assets they had acquired in the 1940s in Finland and in other countries. They kept some companies that played an important role in Soviet-Finnish trade. ${ }^{55}$

After the Soviets had sold off most of the companies, there was little reason to fear foreign attempts to take over the Finnish economy. The Soviets clearly had lost interest in acquiring substantial, new assets, and Western companies expressed only limited interest in investing in Finland. Yet, the Finns continued to ensure that all foreign efforts would be blocked. Not only did the law of 1939 remain in the statute books, but restrictions were even tightened further. In 1967 the Finnish Cabinet decided that the country would take no new foreign investments in forest and mining industries. This was yet another attempt to prevent natural resources from falling into the hands of foreigners, but it is hard to understand why it was necessary. There was little evidence that foreign companies were planning to invest in Finland, and even if they had such desires, the Finnish

\footnotetext{
${ }^{54}$ Suomen Elinkeinoelämän Keskusarkisto (ELKA, The Central Archives for Finnish Business Records). Teollisuuden Keskusliitto, file 447. "Ulkomaalaisen Elinkeinonharjoittamista Suomessa rajoittavia säännöksiä.” Keskuskauppakamari, 17 December 1987.

55 Jensen-Eriksen, Die Ursprünge der „Kreml-AG“; Kuisma, Kylmä sota, kuuma öljy, 97-98; Ahvenainen, EnsoGutzeit Oy, osa II, 491, 493; “Kremlin, Inc.”. Wall Street Journal, 21 December 1954.
} 
government had various administrative means to stop such attempts. ${ }^{56}$ In 1970s, foreign-owned companies' share of the total value added produced by Finnish industry was 5-6 per cent. Foreign companies employed a roughly similar proportion of the industrial labour force. ${ }^{57}$

Yet, the same nationalistic attitudes that encouraged the government to restrict FDI also encouraged it to reduce barriers on trade with the West. Although Finland and the Soviet Union were officially in friendly terms during the Cold War, many Finns regarded their large neighbour as a potential threat, and hence it was wise to reduce economic dependence on it. The best way to do so was to expand trade with non-communist Western countries. Students of economic nationalism have highlighted how many of those new independent states that emerged from the ruins of the Soviet Union in the 1990s have for nationalistic reasons worked hard to redirect their trade towards the West ${ }^{58}$ and have dismantled joint economic institutions with the Russian Federation even in cases where economic reasoning suggested that they should be maintained. This same kind of logic drove Finnish authorities and companies to strengthen their ties with non-communists during the Cold War. From their point of view, these kinds of actions could only strengthen the 'Western' nature of the country in a situation where many observers felt that it belonged to the Soviet sphere of influence. In short, the Finns had little desire to limit their dependence on foreign markets—as long as these markets were mainly Western ones. ${ }^{59}$

\section{Economic liberalism or nationalism?}

It was not only the government circles that opposed foreign investments in Finland. When in 1962 the Swedish electrical engineering company Asea suggested a swap of shares that would give it a minority share of its Finnish competitor Strömberg, this caused a huge outcry in Finland. However, during the following decades, attitudes changed, and in 1987, Asea was allowed to take over Strömberg entirely. ${ }^{60}$ By this time, the national perspective had crumbled. Finnish companies had begun to invest themselves in foreign countries on a substantial scale. Increasingly cosmopolitan enterprises became less and less attached to their country of origin and more interested in expanding

\footnotetext{
56 Jensen-Eriksen, Metsäteollisuus, markkinat ja valtio 1973-1995, 180.

${ }^{57}$ Hjerppe and Ahvenainen, Foreign enterprises, 294.

${ }^{58}$ Shulman, "Nationalist Sources", 383-384; Abdelal, National Purpose.

${ }^{59}$ See for example, Jensen-Eriksen, Läpimurto, chapter 4.

${ }^{60}$ Hoffman, Sähkötekniikan taitaja, 374-382, 485.
} 
abroad. Foreign governments might place obstacles on these investments, if their companies were not allowed to invest in Finland. ${ }^{61}$

Expansion of Finnish trade relations with the West, the decline of Soviet influence and the intensification of the European integration process encouraged Finnish government and companies to strengthen their bonds with Western Europe from the late 1980s onwards. When the European Community (EC) and the members of the European Free Trade Association (EFTA), including Finland, agreed to set up the European Economic Area (EEA) in the early 1990s, this led to the abolishment of traditionally strict restrictions on foreign investments in Finland. The Finnish industry was originally anxious to keep at least some restrictions in place but quickly realised that if they wanted to invest in Western Europe, foreigners should get reciprocal treatment in Finland. It was hard to complain about Asea's actions in Finland, if one's company is doing the same in Sweden and other foreign countries. In the beginning of 1995, Finland eventually became a full member of European Union (EU), and thus ceded part of its sovereignty to Brussels and lost the legal rights to discriminate against EU companies in most respects.

As soon as restrictions were removed, foreign investors rushed in to buy Finnish shares on a substantial scale. The rise of Nokia from a nearly bankrupt conglomerate to a leading global telecommunications firm in a matter of few years, ${ }^{62}$ the EU membership, and the strong growth of the Finnish economy made the country increasingly attractive from a point of view of foreign investors. By early 2000, a majority of the market value of the Finnish publicly quoted companies had been transferred to non-Finnish hands. ${ }^{63}$

Large and often also smaller companies became increasingly international in other respects as well. They expanded their operations abroad, hired foreigners even to top positions and concentrated on earning profits for their (international) owners. Deregulation of financial sector and capital movements in the 1980s had also allowed them to borrow funds from foreign sources on a vast

\footnotetext{
${ }^{61}$ Jensen-Eriksen, Metsäteollisuus, markkinat ja valtio 1973-1995, 180; ELKA. Teollisuuden Keskusliitto, file 448. "ETA-neuvottelutilanne 1.10.1990". Erik Forsman, 5 October 1990; "Teollisuuden tärkeät ETA-kysymykset". 25 September 1990; “Tervetuloa ulkomainen pääoma.” Aku Linnanahde. Talouselämä 39/1986.

${ }^{62}$ Häikiö, Nokia: The Inside Story.

63 Ylä-Anttila, Ali-Yrkkö, and Nyberg, Foreign ownership, 247-248.
} 
scale. National export cartels and other co-operative activities were abolished, and companies began to compete in world markets as independent entities, not as a part of Finnish coalitions. ${ }^{64}$

It seemed that economic nationalism had with quick pace become an outdated way of thinking, which could make little contribution to the Finnish economy and society. The government had lost its desire and ability to regulate capital and trade flows, and export industries had abandoned their traditional coalitions. Taking a closer look, however, reveals that in practice the old notions had not entirely disappeared. In the late 1990s, and the early part of the next decade, there was little reason to place restrictions on foreign activity in Finland, since the Finns themselves seemed to be victors in the new era of global competition. Nokia rapidly became the most important mobile phone producer in the world, and a group of smaller IT companies emerged as important players in world trade. Finnish companies consolidated their position in foreign markets, and the country on the whole seemed to be a shining example of a high tech economy that was particularly able to benefit from global trade.

Yet, it did not last. The position of IT companies began to deteriorate, and more traditional companies cut their production in the country. National perspectives and even xenophobic attitudes rose to surface, and government and business groups began to consider how Finland as a national unit could be saved. Some politicians have even suggested that the Finns should set up new stateowned companies, ${ }^{65}$ a course of action that would have seemed entirely old-fashioned few years earlier. Yet, in an era of global capitalism it is hard to resort to such traditional tools. Nevertheless, a number of scholars argue that economic nationalism in general has not disappeared, but rather its advocates have resorted to new policies to support domestic industries and national competitiveness, attract international capital and highlight their national distinctiveness to acquire a competitive edge. In short, a 'national' perspective survives in a globalised world. ${ }^{66}$

Karl-Erik Michelsen, a Finnish historian, has in a pamphlet highlighted another potential problem with the strong nationalism project: he feels that it increased national cohesion and co-operative spirit but undermined entrepreneurship. Successful entrepreneurs who disrupt existing structures

\footnotetext{
${ }^{64}$ Jensen-Eriksen, Metsäteollisuus, markkinat ja valtio 1973-1995, 171-178.

65 "Keskusta esittää ohjelmassaan kahta uutta valtionyhtiötä.” Helsingin Sanomat 29 January 2011.

${ }^{66}$ Helleiner, "Economic Nationalism as a Challenge", 312; Crane, "Economic nationalism", 75; True, Country Before Money?; Kettunen, Globalisaatio, 45, 210, 216-217; See in particular Kettunen, who has applied this notion to Finnish context.
} 
and gather great fortunes do not fit well in Finnish culture and society, where people value equality and joint projects above everything else. He explicitly points finger at the $19^{\text {th }}$ century Fennoman movement. The tradition of 'pulling together', which nationalism enforced helped Finns to solve a number of huge problems in the course of history, but it is less useful in a competitive global economy, where traditional large companies are shedding jobs in Finland and invest increasingly abroad. Hence, they are no longer similar engines of growth as before. Co-operative traditions and collective activities are still preferred modes of operation in Finland, which might explain why the country has produced relatively few Schumpeterian entrepreneurs, who develop something entirely new and upset conventional ways of action. Hence, the Fennoman traditions make it difficult for Finns to reinvent themselves. ${ }^{67}$

\section{A success story?}

In the course of the $20^{\text {th }}$ century, the Finns built a strong national economy, largely based on domestic raw materials. If the authorities had not placed any restrictions, it would have seemed likely that iron ore would have been shipped to Germany, hydropower to St. Petersburg and timber resources to Britain, Sweden and Germany. These were not theoretical fears; we know from detailed historical studies that foreign companies had concrete plans about the export of these resources at the beginning of the $20^{\text {th }}$ century. Government involvement helped to ensure that these resources formed the basis of growing Finnish manufacturing industries, which eventually became a backbone of the country's economy.

Yet, the Finns probably went too far. It was understandable that the authorities and general population were eager to keep the country's most important natural resources in domestic hands. However, instead of limiting their activities on the protection of the truly vital interests, the Finnish authorities went on to create a system that placed severe obstacles in front of all foreigners who were willing to invest or work in Finland, regardless of what they were going to do. By placing too many restrictions on the few foreigners who were willing to invest or move to Finland, the Finns denied themselves the benefits - money, knowledge and contacts—-that outsiders could have brought to the country. It seems likely that they could have been allowed to establish a presence in many sectors of the economy without endangering the nation's independence.

\footnotetext{
${ }^{67}$ Michelsen, Yrittäjyyden paradoksi.
} 


\section{Bibliography}

Abdelal, Rawi. National Purpose in the World Economy: Post-Soviet States in Comparative Perspective. Ithaca: Cornell University Press, 2001.

Ahvenainen, Jorma. Enso-Gutzeit Oy 1872-1992. Osa I: 1872-1923. Jyväskylä: Enso-Gutzeit, 1992.

_. Enso-Gutzeit Oy 1872-1992. Osa II 1924-1992. Jyväskylä: Enso-Gutzeit Oy, 1992.

Anderson, Benedict. Imagined communities: Reflections on the origin and spread of nationalism. London: Verso, 1983.

Avellan, Mirka. "Margariiniteollisuus globalisaation kourissa - Unileverin elintarvikepuolen edeltäjän Unie/Unionin Suomeen tulo vuosina 1928-1929." Master of Arts thesis, University of Helsinki, 2003.

Blomstedt, Yrjö. Kansallis-Osake-Pankin historia I: 1889-1939. Helsinki, 1989.

Chang, Ha-Joon. "Regulation of Foreign Investment in Historical Perspective." The European Journal of Development Research 16, no. 3 (2004): 687-715.

Crane, George T. "Economic nationalism: Bringing the Nation Back In." Millennium: Journal of International Studies 27, no. 1 (1998): 55-75.

Fougner, Tore. "Economic Nationalism and Maritime Policy in Norway." Cooperation and Conflict 41, no. 2 (2006): 177-201.

Gilpin, Robert. The Political Economy of International Relations. Princeton, New Jersey: Princeton University Press, 1987.

Helleiner, Eric. "Economic Nationalism as a Challenge to Economic Liberalism? Lessons from the 19th Century." International Studies Quarterly 46, no. 3 (2002): 307-29.

Helleiner, Eric, and Andreas Pickel, eds. Economic Nationalism in a Globalizing World. Ithaca and London: Cornell University Press, 2005.

Hjerppe, Riitta. "The Significance of Foreign Direct Investment in a Small Industrializing Economy: The Case of Finland in the Interwar Period." Business and Economic History OnLine 1 (2003).

Hjerppe, Riitta, and Jorma Ahvenainen. "Foreign enterprises and nationalistic control: the case of Finland since the end of the nineteenth century." In Multinational Enterprise in Historical Perspective, edited by Alice Teichova, Maurice Lévy-Leboyer and Helga Nussbaum, 28698. Cambridge and Paris: Cambridge University Press \& Éditions de la Maison des Sciences L'Homme, 1986.

Hjerppe, Riitta, and Juha-Antti Lamberg. "Changing structure and organisation of foreign trade in Finland after Russian rule." In Economic Change and the National Question in Twentieth- 
century Europe, edited by Alice Teichova, Herbert Matis and Jaroslav Pátek, 382-403. Cambridge: Cambridge University Press 2000.

Hoffman, Kai. Sähkötekniikan taitaja: Strömberg 1889-1988. Vaasa: ABB Strömberg, 1989.

Häggman, Kai. Metsän tasavalta: Suomalainen metsäteollisuus politiikan ja markkinoiden ristiaallokossa 1920-1939, Metsäteollisuuden maa 2. Helsinki: Suomalaisen Kirjallisuuden Seura, 2006.

Häikiö, Martti. Nokia: The Inside Story. Helsinki: Edita, 2002.

Jensen-Eriksen, Niklas. "Die Ursprünge der „Kreml-AG“: Die sowjetische Beschlagnahmung deutschen Eigentums in Finnland 1945-1948." In Stalins Wirtschaftspolitik an der sowjetischen Peripherie: Ein Überblick auf der Basis sowjetischer und osteuropäischer Quellen, edited by Walter M. Iber Iber and Peter Ruggenthaler, 183-94. Innsbruck: StudienVerlag, 2011.

. "Kansallinen teollisuus, kansainvälinen ammattitaito: Saksalaiset ammattilaiset ja Suomen modernin metsäteollisuuden synty 1860-1940." In Kahden kulttuurin välittäjä: Hannes Saarisen juhlakirja, edited by Aleksanteri Suvioja and Erkki Teräväinen, 225-37. Helsinki: Helsingin yliopiston Historian laitoksen julkaisuja 20, 2006.

_. Läpimurto: Metsäteollisuus kasvun, integraation ja kylmän sodan Euroopassa 1950-1973, Metsäteollisuuden maa 4. Helsinki: Suomalaisen Kirjallisuuden Seura, 2007.

. "Metsäteollisuus, markkinat ja valtio 1973-1995." In Kriisi ja kumous: Metsäteollisuus ja maailmantalouden murros 1973-2008, edited by Markku Kuisma, 27-189. Helsinki:

Suomalaisen Kirjallisuuden Seura, 2008.

. "A Potentially Crucial Advantage: Export Cartels as a Source of Power for Weak Nations." Revue Économique 63, no. 6 (2013): 1085-1104.

Keskisarja, Teemu. Afäärifennomaanit: Paloheimo-veljekset suurliikemiehinä ja yhteiskunnallisina vaikuttajina. [Helsinki]: WSOY, 2006.

Kettunen, Pauli. Globalisaatio ja kansallinen me: Kansallisen katseen historiallinen kritiikki Tampere: Vastapaino, 2008.

. "The Tension between the Social and the Economic - A Historical Perspective on a Welfare State." In The Road to Prosperity. An Economic History of Finland, edited by Jari Ojala, Jari Eloranta and Jukka Jalava, 285-313. Helsinki: Suomalaisen Kirjallisuuden Seura, 2006.

Kuisma, Markku. "Cooperation in Competition: Finland, an example of successful development, 1918-1939." In Uneven Development in Europe 1918-1938, edited by Jean Batou and Thomas David, 409-45. Geneva: International Economic and Social History Publications, 1998. 
. "Government Action, Cartels and National Corporations - The Development Strategy of a Small Peripheral Nation during the Period of Crisis and Economic Disintegration in Europe (Finland, 1918-1939)." Scandinavian Economic History Review XLI, no. 3 (1993): 242-68.

. A History of Outokumpu. [Helsinki]: [Outokumpu], 1989.

. Kylmä sota, kuuma öljy: Neste, Suomi ja kaksi Eurooppaa 1948-1979. Porvoo: Werner Söderström Osakeyhtiö, 1997.

- Sodasta syntynyt: Itsenäisen Suomen synty Sarajevon laukauksista Tarton rauhaan 19141920. Helsinki: Werner Söderström Osakeyhtiö, 2010.

Levi-Faur, David. "Economic nationalism: from Friedrich List to Robert Reich." Review of International Studies 23, no. 3 (1997): 359-70.

Lyytinen, Eino. Pohjola-yhtiöt sata vuotta. [Helsinki]: [Pohjola-yhtiöt], 1991.

Michelsen, Karl-Erik. Sähköstä ja Suolasta Syntynyt: Finnish Chemicals Oy. Nokia Chemicals 1937-1987. Jyväskylä: Nokia Chemicals, 1989.

—. Yrittäjyyden paradoksi. Helsinki: EVA, 2005.

Michelsen, Karl-Erik, and Markku Kuisma. "Nationalism and Industrial Development in Finland." Business and Economic History,. Second Series, vol. 21 (1992): 343-53.

Myllyntaus, Timo. Electrifying Finland: The Transfer of a New Technology into a Late Industrialising Economy. Basingstoke: Macmillan in association with ETLA, 1991.

—. "The Finnish Model of Technology Transfer." Economic Development and Cultural Change 38, no. 3 (1990): 625-43

Nakano, Takeshi. "Theorising economic nationalism." Nations and Nationalism 10, no. 3 (2004): 211-29.

Ojala, Jari, Jari Eloranta, and Jukka Jalava, eds. The Road to Prosperity. An Economic History of Finland. Helsinki: Suomalaisen Kirjallisuuden Seura, 2006.

Ojala, Jari, and Petri Karonen. "Business: Rooted in Social Capital over the Centuries." In The Road to Prosperity. An Economic History of Finland, edited by Jari Ojala, Jari Eloranta and Jukka Jalava, 93-126. Helsinki: Suomalaisen Kirjallisuuden Seura, 2006.

Pickel, Andreas. "Explaining, and explaining with economic nationalism." Nations and Nationalism 9, no. 1 (2003): 105-27.

Shulman, Stephen. "Nationalist Sources of International Economic Integration." International Studies Quarterly 44, no. 3 (2000): 365-90.

Silvennoinen, Oula. Paperisydän: Gösta Serlachiuksen elämä. Helsinki: Kustannusosakeyhtiö Siltala, 2012. 
Särkkä, Timo, Maare Valtonen, Olli Turunen, and Heli Valtonen, The economic and social networks of business leaders: Immigrant businessmen in the nineteenth century Finnish economy. Revised version of the paper presented at the $14^{\text {th }}$ Annual Conference of the European Business History Association 2010 University of Glasgow 26-28th August 2010.

True, Jacqui. "Country Before Money? Economic Globalization and National Identity in New Zealand." In Economic Nationalism in a Globalizing World, edited by Eric Helleiner and Andreas Pickel, 202-19. Ithaca and London: Cornell University Press, 2005.

Ylä-Anttila, Pekka, Jyrki Ali-Yrkkö, and Martti Nyberg. "Foreign ownership in Finland: Boosting firm performance and changing corporate governance ." In The Internationalisation of Asset Ownership in Europe, edited by Harry Huizinga and Lars Jonung, 247-77. Cambridge: Cambridge University Press, 2005. 